\title{
Peramalan Penjualan dengan Metode Exponential Smoothing (Studi Kasus : Penjualan Bakso Kemasaan/Kiloan Rumah Bakso Bang Ipul)
}

\author{
Hisyam Ihsan ${ }^{1}$, Rahmat Syam ${ }^{1}$, Fahrul Ahmad ${ }^{1, a)}$ \\ ${ }^{1)}$ Jurusan Matematika, Fakultas Matematika dan Ilmu Pengetahuan Alam, Universitas Negeri \\ Makassar, 90224 \\ a)lafahrul@gmail.com
}

\begin{abstract}
Abstrak. Peramalan penjualan memungkinkan sebuah perusahan memilih kebijakan yang optimal untuk membuat keputusan yang sesuai dan mempertahankan efisiensi dari kegiatan operasional. Rumah Bakso Bang Ipul adalah salah satu usaha yang melakukan penjualan yakni penjualan bakso kemasaan/kiloan. Oleh sebab itu,. Rumah Bakso Bang Ipul sangat memerlukan peramalan penjualan untuk meningkatkan keuntungan dan menghindari terjadinya kelebihan atau kekurangan persedian bakso kemasaan/kiloan. Penelitian ini dilakukan peramalan dengan metode exponential smoothing. Adapun parameter atau a yang digunakan dalam meramalkan penjualan adalah $a=0.1,0.2,0.3,0.4,0.5,0.6,0.7,0.8$, dan 0.9. Singel exponential smoothing melakukan perbandingan dalam menentukan nilai a, dengan mencari nilai a tersebut secara trial and error sampai menemukan a yang memiliki error minimum dengan pencarian menggunakan metode mean absolute error (MAE) dan metode Mean Squaered error (MSE). Sehingga dipilih $a=0.1$ dengan nilai $M A E=6.23$ dan nilai $M S E=58.32$. berdasarkan hasil ini, dengan menggunakan metode singel exponential smoothing dan $a=0.1$ diperoleh hasil peramalan penjualan bakso bang ipul pada bulan juni 2018 sebanyak 48 kilogram.
\end{abstract}

Kata Kunci: Peramalan, Metode Exponential Smoothing, Metode Singel Exponential Smoothing

\begin{abstract}
Sales forecasting enables an optimal policy of the company had to make the appropriate decision and maintain the efficiency of operational activities. Rumah Bakso Bang Ipul is a business that sells packaged meatballs. Therefore, Rumah Bakso Bang Ipul is in need of sales forecasting to increase profit and avoid the occurrence or lack of supply of packaged meatballs. This research was conducted by the method of exponential smoothing forecasting. As for parameter or a used predicting sales is $a=$ $0.1,0.2,0.3,0.4,0.5,0.6,0.7,0.8$, and 0.9. single exponential smoothing do a comparison in determining the value of a, by searching for the value of such a trial and error to find a that has minimum error with search method using the mean absolute error (MAE) and mean squared error (MSE). So that selected a $=0.1$ with $M A E$ value $=6.23$ and MSE Value $=58.32$. Based on these results, using the method of single exponential smoothing and retrieved results forecasting Rumah Bakso Bang Ipul in July 2018 as much as 48 kilograms. Keywords: Forecasting, Method of exponential smoothing, Method of single exponential smoothing.
\end{abstract}

\section{PENDAHULUAN}

Dalam suatu usaha, toko ataupun perusahan baik kuliner, barang ataupun jasa. Strategi penjualan sangat diperlukan untuk mendapatkan keuntungan maksimum. Salah satu cara yang dilakukan penjualan ini adalah dengan melakukan prediksi penjualan (Sartika \& Nasution, 2017). Peramalan pejualan merupakan hal yang penting dalam sebuah toko atau perusahaan karena dengan menggunakan peramalan, toko dapat memprediksi jumlah barang yang harus ada di dalam 
gudang. Stok barang terlalu banyak menyebabkan terjadinya penumpukan barang di gudang yang pada akhirnya berpengaruh terhadap perputaran uang karena barang yang tinggal atau kadaluarsa. Stok barang yang terlalu sedikit juga berpengaruh terhadap perputaran keuangan karena barang yang habis tidak dapat memenuhi permintaan pelanggan. Stok barang yang terlalu banyak dan terlalu sedikit ini disebabkan oleh pemilik toko ataupun usaha yang tidak tahu seberapa banyak barang yang akan terjual untuk periode berikutnya (Hartono, Dwijana \& Handiwidjojo., 2012).

Peramalan adalah suatu metode untuk memperkirakan suatu nilai dimasa depan dengan menggunakan data masa lalu. Peramalan juga dapat diartikan sebagai seni dan ilu untuk memperkirakan kejadian pada masa yang akan datang, sedangkan aktivitas peramalan adalah suatu fungsi bisnis yang berusaha memperkirakan pejualan atau pengguaan suatu produk sehingga produk-produk itu dapat dibuat dalam kuantitas yang tepat (Wardah \& Iskandar, 2016)

Penelitian tentang peramalan penjualan telah banyak dilakukan sebelumnya (Fachurrazi; 2015, Wardah \& Iskandar; 2016). Fachurrazi (2015) meramalan penjualan obat menggunakan metode single exponential smoothing pada toko obat bintang geurugok dimana menggunakan parameter alpha yang berbeda-beda, mencari nilai alpha terbaik secara trial/acak sampai menemukan alpha dengan error minimum. Wardah dan Iskandar (2016) melakukakan analisis peramalan penjualan produk keripik pisang kemasaan bungkus dengan menggunakan data dari home industry arwana food tembilahan. Mereka menggunakan tiga metode berbeda yaitu metode moving average, metode exponential smoothing dan metode trend anaylisis. Memilih metode terbaik dengan membandingkan tingkat kesalahan.

Exponential smoothing merupakan peralaman yang mengikuti pola fluktuasi data yang diobservasi pada suatu periode untuk ramalan pada masa yang akan datang dengan cara melicinkan atau disebut smoothing, dan mengurangi fluktuasi ramalan tersebut (Wardhani \& Pereira, 2010). Penelitian ini melakukan peramalan penjualan bakso kemasaan/kiloan pada Rumah Bakso Bang Ipul dengan menggunakan data penjualan pada bulan-bulan sebelumnya dengan menggunakan metode exponential smoothing. Rumah Bakso Bang Ipul merupakan salah satu usaha kecil yang bergerak dibidang kuliner yakni pejualan bakso kemasaan/kiloan, dimana selama ini jumlah produksi hanyalah berdasarkan intuisi dari pengelolah usaha, sehingga apabila penjualan meningkat maka stok bakso kemasan/kiloan kekurangan dan begitupun sebaliknya bila penjualan menurun bakso akan tinggal dan biasa jadi kadaluarsa sehingga mengakibatkan kerugian pada keuangan usaha. Oleh karena itu perlu adanya peramalan penjualan yang dihitung berdasarkan pola data masa lalu.

\section{KAJIAN PUSTAKA}

Peramalan adalah suatu metode untuk memperkirakan suatu nilai dimasa depan dengan menggunakan data masa lalu. Peramalan juga dapat diartikan sebagai seni dan ilmu untuk memperkirakan kejadian pada masa yang akan datang, sedangkan aktivitas peramalan adalah aktivitas suatu fungsi bisnis yang berusaha memperkirakan penjualan atau penggunaan suatu produk sehingga produk-produk itu dapat dibuat dalam kuantitas yang tepat (Wardah \& Iskandar, 2016).

Said (2011) menjelaskan proses peramalan terdiri dari langkah-langkah sebagai berikut

1. Penentuan Tujuan

2. Pengembangan Model

3. Pengujian Model

4. Penerapan Model

5. Revisi dan Evaluasi.

Deret Berkala (Time Series) adalah sekumpulan data yang dicatat selama periode tertentu, umumnya berupa data mingguan, bulanan, kuartal, atau tahunan. Data berkala (Time Series) adalah data yang dikumpulkan dari waktu ke waktu untuk menggambarkan perkembangan suatu 
kegiatan (perkembangan produksi, harga, hasil penjualan, jumlah personil, penduduk, jumlah kecelakan, jumlah kejahatan dan lain sebagainya (Said, 2011).

Langkah penting dalam memilih suatu metode deret waktu/berkala yang tepat adalah dengan mempertimbangkan jenis pola data, sehingga metode yang paling tepat dengan pola tersebut dapat diuji. Pola data dapat dibedakan menjadi empat jenis, yaitu

1. Pola Horizontal, terjadi bilamana nilai berfluktuasi di sekitar nilai rata-rata yang konstan

2. Pola Musiman, terjadi bilamana suatu dere dipengaruhi oleh faktor musiman.

3. Pola Siklis, terjadi bilamana suatu data dipengaruhi oleh fluktuasi ekonomi jangka panjang,

4. Pola Trend, terjadi bilamana terdapat kenaikan atau penurunan sekuler jangka panjang.

Metode Exponential Smoothing adalah metode yang menunjukkan pembobotan menurun secara eksponensial terhadap nilai pengamatan yang lebih lama. Terdapat satu atau lebih parameter penulisan yang ditentukan secara eksplisit dan hasil pilihan ini menentukan bobot yang dikenakan pada nilai observasi (Makridakis, Spyros \& Wheelwright., 1999).

Metode peramalan exponential smoothing adalah suatu prosedur yang mengulang perhitungan secara terus menerus dengan menggunakan data terbaru. Metode ini terdiri atas tunggal, ganda (double), dan triple. Metode single Exponential smoothing juga dikenal sebagai simple exponential smoothing yang digunakan pada peramalan jangka pendek, biasanya 1 bulan kedepan. Model mengasumsikan bahwa data berfluktuasi di sekitar nilai mean yang tetap atau menunjukkan pola horizontal, tanpa trend dan musiman atau pola pertumbuhan konsisten (Makridakis, Spyros \& Wheelwright., 1999).

$$
F_{t+1}=a X_{t}+(1-a) F_{t}
$$

Persamaan (1) merupakan bentuk umum yang digunakan dalam menghitung ramalan dengan metode single exponential smoothing. metode ini banyak mengurangi masalah penyimpangan data, karena tidak perlu lagi menyimpan semua data historis atau sebagian daripadanya.

Ketepatan dari suatu metode peramalan merupakan kesesuaian dari suatu metode yang menunjukkan seberapa jauh model peramalan tersebut mampu meramalakan data aktual. Nilai hasil peramalan akan selalu berbeda dengan data aktual. Perbedaan antara nilai peramalan dengan data aktual disebut kesalahan peramalan (error). Meskipun suatu jumlah kesalahan peramalan tidak dapat dihindari, namun tujuan peramalan adalah agar kesalahan diminimalisir (Widjajati, Soehardjoepri \& Fani., 2017).

Metode peramalan yang memiliki nilai kesalahan hasil peramalan terkecil, akan dianggap sebagai metode yang cocok untuk digunakan. Terdapat banyak metode untuk melakukan perhitungan kesalahan peramalan. Metode yang digunakan dalam peramalan ini adalah mean absolute error dan mean squared error.

Mean absolute error (MAE) adalah rata-rata nilai absolute error dari kesalahan meramal, MAE dihitung dengan persamaan (2)

$$
M A E=\frac{\sum\left|X_{t}-F_{t}\right|}{n}
$$

Mean squared error (MSE) adalah rata-rata dari kesalahan peramalan yang dikuadratkan, MSE dihitung dengan menggunakan persamaan (3)

$$
M S E=\frac{\sum\left(X_{t}-F_{t}\right)^{2}}{n}
$$

\section{METODE PENELITIAN}

Penelitian ini termasuk penelitian terapan. Tujuan penelitian untuk meramalkan penjualan menggunakan metode exponential smoothing. Data yang digunakan adalah Data penjualan Rumah Bakso Bang Ipul. Metode penelitian yang digunakan adalah studi kontemporer melalui 
kajian pustaka yakni dengan mengumpulkan literatur-literatur yang berkaitan dengan metode exponential smoothing dan manipulasi matematis permasalahan penjualan dari sumber-sumber yang berkaitan den mendukung penelitian ini.

Prosedur penelitian yang diterapkan dalam penelitian ini guna mencapai tujuan penelitian adalah membuat Scatter Diagram, memilih metode exponential smoothing berdasarkan pola dari data time series yang ada, menentukan nilai $\alpha$, menghitung nilai kesalahan peramalan, kriteria pemilihan metode peramalan yang terbaik.

\section{HASIL DAN PEMBAHASAN}

\section{Hasil Penelitian}

\section{Membuat Scatter Diagram}

Berdasarkan data banyaknya penjualan pada Rumah Bakso Bang Ipul sejak Januari 2016 sampai Juni 2018 dapat disajikan ke dalam scatter diagram dengan bantuan software excel ditambahkan garis trend, pola dan rata-rata dapat dilihat pada Gambar 1

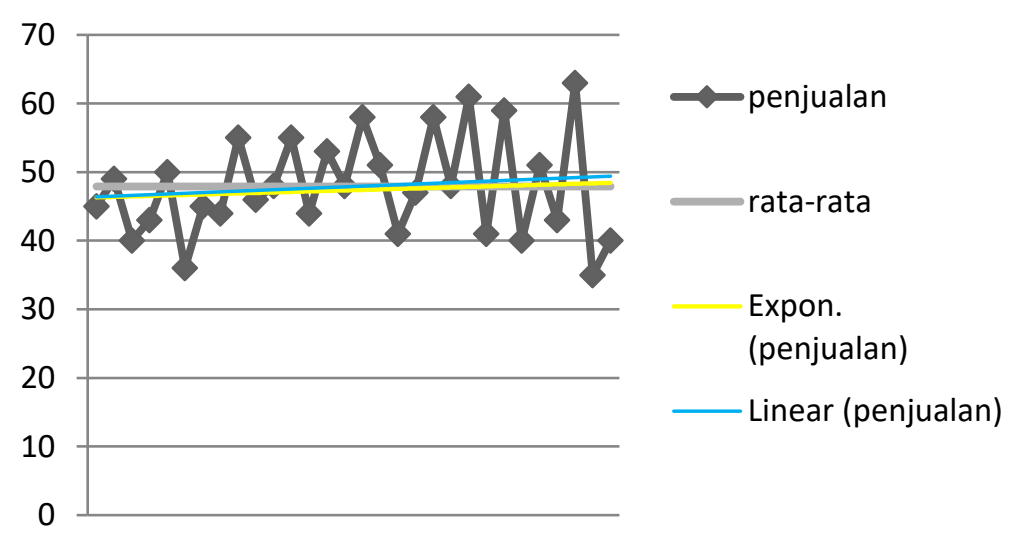

GAMBAR 1. Grafik Data Penjualan Bakso Bang Ipul

\section{Memilih Metode Exponential Smoothing yang Tepat}

Gambar 1 data memperlihatkan pola horizontal maka peramalan menggunakan metode single exponential smoothing. sehingga untuk mencari $F_{t+1}$ dengan menggunakan persamaan (1). Dengan menggunakan $\alpha=0.1,0.2,0.3,0.4,0.5,0.6,0.7,0.8$ dan 0.9 maka $F_{t+1}$ dapat diperoleh sebagai berikut

5. Untuk $\alpha=0.1$

$$
\begin{aligned}
F_{t+1} & =0.1 X_{t}+(1-0.1) F_{t} \\
& =0.1 X_{t}+0.9 F_{t}
\end{aligned}
$$

6. Untuk $\alpha=0.2$

$$
\begin{aligned}
F_{t+1} & =0.2 X_{t}+(1-0.2) F_{t} \\
& =0.2 X_{t}+0.8 F_{t}
\end{aligned}
$$

7. Untuk $\alpha=0.3$

$$
\begin{aligned}
F_{t+1} & =0.3 X_{t}+(1-0.7) F_{t} \\
& =0.3 X_{t}+0.7 F_{t}
\end{aligned}
$$

8. Untuk $\alpha=0.4$ 
9. Untuk $\alpha=0.5$

$$
\begin{aligned}
F_{t+1} & =0.4 X_{t}+(1-0.4) F_{t} \\
& =0.4 X_{t}+0.6 F_{t}
\end{aligned}
$$

10. Untuk $\alpha=0.6$

$$
\begin{aligned}
F_{t+1} & =0.5 X_{t}+(1-0.5) F_{t} \\
& =0.5 X_{t}+0.5 F_{t}
\end{aligned}
$$

11. Untuk $\alpha=0.7$

$$
\begin{aligned}
F_{t+1} & =0.6 X_{t}+(1-0.6) F_{t} \\
& =0.6 X_{t}+0.4 F_{t}
\end{aligned}
$$

12. Untuk $\alpha=0.8$

$$
\begin{aligned}
F_{t+1} & =0.7 X_{t}+(1-0.7) F_{t} \\
& =0.7 X_{t}+0.3 F_{t}
\end{aligned}
$$

13. Untuk $\alpha=0.9$

$$
\begin{aligned}
F_{t+1} & =0.8 X_{t}+(1-0.8) F_{t} \\
& =0.8 X_{t}+0.2 F_{t}
\end{aligned}
$$

$$
\begin{aligned}
F_{t+1}= & 0.9 X_{t}+(1-0.9) F_{t} \\
& =0.9 X_{t}+0.1 F_{t}
\end{aligned}
$$

Untuk $t=1$ karena pada saat $t=1$ nilai single exponential smoothing belum tersedia, maka dapat dilakukan dengan menetapkan nilai single exponential smoothing sama dengan nilai data pertama atau $F_{1}=X_{1}=45$. dengan menggunakan $\alpha=0.1,0.2,0.3,0.4,0.5,0.6,0.7$, 0.8 dan 0.9 sehingga diperoleh nilai $F_{2}$ sebagai berikut

14. Untuk $\alpha=0.1$

$$
\begin{gathered}
F_{2}=0.1 X_{1}+0.9 F_{1} \\
=0.1(45)+0.9(45) \\
=45
\end{gathered}
$$

15. Untuk $\alpha=0.2$

$$
\begin{gathered}
F_{2}=0.2 X_{1}+0.8 F_{1} \\
=0.2(45)+0.8(45) \\
=45
\end{gathered}
$$

16. Untuk $\alpha=0.3$

$$
\begin{gathered}
F_{2}=0.3 X_{1}+0.7 F_{1} \\
=0.3(45)+0.7(45) \\
=45
\end{gathered}
$$

17. Untuk $\alpha=0.4$

$$
\begin{gathered}
F_{2}=0.4 X_{1}+0.6 F_{1} \\
=0.4(45)+0.6(45) \\
=45
\end{gathered}
$$

18. Untuk $\alpha=0.5$

$$
\begin{gathered}
F_{2}=0.5 X_{1}+0.5 F_{1} \\
=0.5(45)+0.5(45) \\
=45
\end{gathered}
$$

19. Untuk $\alpha=0.6$ 


$$
\begin{gathered}
F_{2}=0.6 X_{1}+0.4 F_{1} \\
=0.6(45)+0.4(45) \\
=45
\end{gathered}
$$

20. Untuk $\alpha=0.7$

$$
\begin{gathered}
F_{2}=0.7 X_{1}+0.3 F_{1} \\
=0.7(45)+0.3(45) \\
=45
\end{gathered}
$$

21. Untuk $\alpha=0.8$

$$
\begin{gathered}
F_{2}=0.8 X_{1}+0.2 F_{1} \\
=0.8(45)+0.2(45) \\
=45
\end{gathered}
$$

22. Untuk $\alpha=0.9$

$$
\begin{gathered}
F_{2}=0.9 X_{1}+0.1 F_{1} \\
=0.9(45)+0.1(45) \\
=45
\end{gathered}
$$

Untuk $t=2$ dapat dihitung dengan menggunakan nilai $X_{2}$ dan $F_{2}$ yang sudah diperoleh sebelumnya dengan menggunakan $\alpha=0.1,0.2,0.3,0.4,0.5,0.6,0.7,0.8$ dan 0.9 sehingga diperoleh nilai $F_{3}$ dan begitupun untuk nilai $t$ yang lainnya.

\section{Menghitung Kesalahan Peramalan}

Diperoleh nilai mean absolute error (MAE) untuk $\alpha=0.1$ adalah 6.23, untuk $\alpha=0.2$ adalah 6.33, untuk $\alpha=0.3$ adalah 6.61, untuk $\alpha=0.4$ adalah 6.91, untuk $\alpha=0.5$ adalah 7.26, untuk $\alpha=0.6$ adalah 7.67, untuk $\alpha=0.7$ adalah 8.15, untuk $\alpha=0.8$ adalah 8.68 dan untuk $\alpha=$ 0.9 adalah 9.41. Untuk nilai mean squared error (MSE) diperoleh untuk $\alpha=0.1$ adalah 58.32, untuk $\alpha=0.2$ adalah 61.01, untuk $\alpha=0.3$ adalah 65.30, untuk $\alpha=0.4$ adalah 70.85, untuk $\alpha=0.5$ adalah 77.63, untuk $\alpha=0.6$ adalah 85.75, untuk $\alpha=0.7$ adalah 95.48, untuk $\alpha=$ 0.8 adalah 107.30 dan untuk $\alpha=0.9$ adalah 121.90 .

\section{Meramalkan dengan Menggunakan Metode Terbaik}

Berdasakan pola data, nilai MAE dan MSE maka dipilih metode peramalan untuk meramalkan penjualan bakso kemasaan/kiloan Rumah Bakso Bang Ipul dengan Menggunakan metode single exponential smoothing dengan $\alpha=0.1$. sehingga $F_{30+1}$ dapat dihitung sebagai berikut.

$$
\begin{gathered}
F_{31}=0.1 X_{30}+0.9 F_{30} \\
=0.1(40)+0.9(48.51) \\
=47.66
\end{gathered}
$$

\section{KESIMPULAN}

Untuk melakukan peramalan digunakan metode exponential smoothing berdasarkan data jumlah penjualan sejak Januari 2016 sampai dengan Juni 2018 dimana pola data memperlihatkan pola horizontal. Diperoleh nilai MAE dengan $\alpha=0.1$ paling kecil dibandingkan nilai MAE dengan $\alpha$ yang lain yaitu sebesar 6.23. dan nilai MSE dengan $\alpha=0.1$ paling kecil dibandingkan nilai MSE dengan $\alpha$ yang lain yaitu sebesar 58.32. Sehingga metode exponential smoothing yang cocok untuk peramalan banyaknya penjualan bakso kemasaan/kiloan Rumah Bakso Bang Ipul 
adalah metode single exponential smoothing dengan $\alpha$ sebesar 0.1. Adapun hasil ramalan banyaknya penjualan bakso kemasaan/kiloan pada Rumah Bakso Bang Ipul pada bulan Juli 2018 adalah sebesar 48 kilogram.

Adapun saran untuk penelitian selanjutnya adalah menggunakan alpa yang lebih kecil dari 0.1, membandingkan ketiga metode exponential smoothing, dan menggunakan perhitungan nilai kesalahan peramalan dengan metode yang dapat menghitung tingkat akurasi peramalan metode exponential smoothing.

\section{DAFTAR PUSTAKA}

Fachrurrazi, S. (2015). Peramalan Penjualan Obat Menggunakan Metode Single Exponential Smoothing Pada Toko Obat Bintang Geurugok. Techsi, 6(1).19-30.

Hartono, A., Dwijana, D., \& Handiwidjojo, W. (2012). Perbandingan Metode Single Exponential Smoothing dan Metode Exponential Smoothing Trend (Holt's Method) untuk meramalkan Penjualan. Eksis, 5(1). 8-18.

Makridakis, Spyros \& Wheelwright, S. (1999). Metode dan Aplikasi Peramalan. Jakarta: Erlangga

Said, S. (2011). Peramalan (Forecasting) Volume Penjualan dengan Menggunakan Metode Exponential Smoothing. (Skripsi, tidak dipublikasikan). Universitas Islam Negeri Alauddin, Makassar.

Sartika, D. \& Nasution, H. (2017). Penggunan Metode Smoothing Eksponensial Dalam Meramalkan Pergerakan Inflasi di Kota Medan. Karismatika, 3(1). 24-35.

Wardah, S. \& Iskandar. (2016). Analisis Peramalan Penjualan Produk Keripik Pisang Kemasan Bungkus (Studi Kasus : Home Industry Arwana Food Tembilahan. Teknik Industri, 11(3).135-142.

Wardhani, A. R. \& Pereira, S. M. (2010). Studi Analisis Peramalan Dengan Metode Deret Berkala. Widya Teknika, 18(3). 1-6.

Widjajati, F. A., Soehardjoepri \& Fani, E. (2017). Menentukan Penjualan Produk Terbaik Di Perusahaan X Dengan Metode Winter Exponential Smoothing dan Metode Event Based. Limits, 14(1). 25-35. 